\title{
Effluent conditioning of biodiesel production for biological treatment using clay as a separation coadjutant
}

\author{
Condicionamento de efluentes da produção de biodiesel para tratamento biológico utilizando
} argila como coadjuvante de separação

\author{
L. C. Correia ${ }^{1}$, R. R. Silva ${ }^{2}$, F. R. M. França², G. F. Silva ${ }^{2}$, D. F. Coelho ${ }^{*}$, J. J. \\ Marques $^{3}$
}

\author{
${ }^{1}$ Department of Chemical Engineering / Laboratory of Environmental Biotechnology / Centre of Exact and Earth \\ Sciences, Federal University of Sergipe, 49100-000, São Cristóvão-SE, Brazil \\ ${ }^{2}$ Nucleus of Petroleum Engineering / Laboratory of Alternative Technologies / Centre of Exact and Earth Sciences, \\ Federal University of Sergipe, 49100-000, São Cristóvão-SE, Brazil
}

${ }^{3}$ Department of Environmental Engineering / Laboratory of Atmospheric Pollution Control / Centre of Exact and Earth Sciences, Federal University of Sergipe, 49100-000, São Cristóvão-SE, Brazil

\author{
*diegofcoelho@gmail.com
}

(Recebido em 05 de novembro de 2019; aceito em 07 de abril de 2020)

\begin{abstract}
Biodiesel is a renewable, non-toxic and sustainable biofuel, considered to be the main candidate for a fossil fuel alternative in many countries. However, its manufacturing process results in about 0.2 to $3 \mathrm{~L}$ of effluent per litre of biodiesel produced. In addition to an inherently high organic load, its composition includes byproducts, traces of unreacted chemicals and catalysts, which inhibit microorganism growth and prevent its direct treatment by tertiary methods. In this context, this work aims to evaluate the combination of the coagulation-flocculation technique with dissolved air flotation (DAF). Real wastewater samples were obtained by synthesising biodiesel from soybean oil in-loco and performing the required washing procedures. The highest turbidity reduction efficiency $\left(92.03 \%\right.$ ) was obtained using $1200 \mathrm{mg} \cdot \mathrm{L}^{-1}$ of clay. By using response surface methodology, it was possible to analyse the effect of the chosen experimental factors and show that the best results $(81.28 \%, 58.95 \%$ and $89.34 \%$ for turbidity, oil and grease and chemical oxygen demand - respectively) were obtained using $925 \mathrm{mg} \cdot \mathrm{L}^{-1}$ of clay and $1000 \mathrm{mg} \cdot \mathrm{L}^{-1}$ of coagulant. Ultimately, clay proved to be an efficient coadjutant in the removal of organic matter, oils, grease, suspended solids and soluble organic matter from the biodiesel wastewater. Moreover, its low cost over traditional flocculants makes it an attractive alternative to industrial wastewater treatment processes.

Keywords: biodiesel wastewater, dissolved air flotation, coagulation-flocculation.
\end{abstract}

O biodiesel é um biocombustível renovável, não tóxico e sustentável, portanto é considerado a principal alternativa para substituir os combustíveis fósseis em diversos países, como os Estados Unidos, Alemanha e França. O processo de fabricação de biodiesel resulta em cerca de 0,2 a $3 \mathrm{~L}$ de efluente por litro de biodiesel produzido, que quando descartado inadequadamente no meio ambiente pode resultar em grave impacto ambiental. Nesse contexto, esse trabalho avaliou o efeito da associação entre as técnicas de coagulação/floculação com a flotação por ar dissolvido (FAD) para remoção parcial da carga orgânica, condicionando o efluente para o tratamento biológico ou até mesmo descarte direto. Os ensaios foram realizados em amostras reais de efluente, obtidas através da lavagem de biodiesel produzido a partir de óleo de soja. A maior eficiência na remoção de turbidez $(92,03 \%)$ foi obtida utilizando-se a concentração máxima de argila (1200 mg/L). Considerando os resultados obtidos, apresentados sob a forma de superfícies de reposta e as respectivas curvas de níveis, os melhores resultados foram obtidos utilizando-se $925 \mathrm{mg} / \mathrm{L}$ de argila e $1000 \mathrm{mg} / \mathrm{L}$ de coagulante. Assim, a argila se mostrou eficiente como agente coadjuvante de separação para remoção de matéria orgânica, sobretudo de óleos e graxas, sólidos suspensos e matéria orgânica solúvel. Além disso, seu baixo custo, em relação aos floculantes tradicionais, torna-a uma alternativa atrativa para os processos de tratamento de efluentes industriais.

Keywords: Efluente de Biodiesel, Flotação por Ar Dissolvido, Coagulação-Floculação.

\section{INTRODUCTION}

The recent worldwide attention given to renewable energy sources is a result of raised concerns over long-term effects of global warming and new developments in the petroleum geopolitics [1]. In this context, owing to several other advantages regarding their sustainability, technical 
adaptability and environmental impact, biofuels are considered a promising alternative for mitigating greenhouse gas emissions [2].

Biodiesel is a renewable, non-toxic fuel produced through the transesterification of triglycerides [3] and considered to be the main alternative to fossil fuels in many countries [4]. The production consists of the chemical reaction of lipids - fats or oils of vegetable or animal origin - with alcohol in excess, in the presence of a catalyst [5]. Subsequently, the biodiesel must be washed thoroughly, in order to remove by-products and other contaminants. This process is well-known as biodiesel washing (BW) and yields an effluent rich in unconverted oil, traces of the catalyst and significant amounts of alcohol used in production [6,7]. For each litre of biodiesel produced, approximately 0.2 to $3 \mathrm{~L}$ of wastewater is formed during BW [8].

According to CONAMA Resolution No. 430 of 2011 [4], inappropriate disposal of this effluent, contrary to the current environmental legislation, may result in harmful effects on the environment. Therefore, in order to comply with this resolution, wastewater should not be disposed of directly into the environment without a proper pre-treatment.

Biodiesel wastewater treatment is complex due to the high variation of its composition and exceptionally high content levels of oil, grease, chemical oxygen demand (COD), total organic carbon (TOC) and suspended solids (SS). Despite the existence of several wastewater treatment processes for BW effluent [9], the research community has focused its efforts on developing a costeffective method that can reduce successfully the content of contaminants and can be integrated into a biodiesel production plant. The current wastewater treatment solution is a combination of physico-chemical processes, which reach higher treatment efficiency than any single-step techniques [10].

Among those, the coagulation-flocculation $(\mathrm{CF})$ process is considered to be the most promising pre-treatment step since it is well-known and capable of conditioning the effluent composition for a subsequent tertiary method [11]. Coagulation occurs with the addition of coagulant agents, which destabilise the colloidal suspension rapidly, and leads to sedimentation - or flotation - of the particle aggregates and a decrease in suspended solids content, oil and grease (OG), COD and biological oxygen demand (BOD) $[12,13]$.

While aluminium sulphate is the most commonly used coagulant in wastewater treatment, providing excellent results for industries in several areas [14], the application of clay as an additive provides conditions for industries to treat its effluents and dispose of them with virtually no impact and at lower costs [15] compared to commercial polymeric agents.

Dissolved Air Flotation (DAF) is an effective method for removing low density particles in suspension and reducing turbidity. The air is dissolved under high pressure in a saturator vessel and then decompressed in the flotation tank under atmospheric pressure leading to formation of microbubbles. The microbubbles bond to the particles, increasing their buoyancy and allowing them to rise to the surface [16].

In this manuscript we report the application of a combined CF-DAF process - using clay as coadjutant agent - in the pre-treatment of wastewater produced during biodiesel washing, a required purification step in the biofuel production. Combined, these techniques have the potential to reduce considerably the organic load in the effluent, conforming it to the constraints of tertiary treatment method.

\section{MATERIALS AND METHODS}

\subsection{Biodiesel Washing Wastewater (BWW)}

Wastewater samples were provided by the Laboratory of Alternative Technologies (LTA) of the Federal University of Sergipe, were the biodiesel washing (BW) effluent was obtained from the biodiesel production on a bench-scale process. The process produces biodiesel through the transesterification of commercial soybean oil using methanol in a ratio of 1:6 (on a molar basis), with anhydrous potassium hydroxide as the catalyst (1\% of the oil mass). After the separation of the glycerine (co-product), the biodiesel was washed successively with distilled water at $90^{\circ} \mathrm{C}$ until the washing water (effluent) reached neutral $\mathrm{pH}$. 


\subsection{Effluent Characterization}

\subsubsection{Turbidity}

The turbidity was determined by the nephelometric technique [17], using a Lutron turbidimeter model TU-2016.

\subsubsection{Content of Oils and Greases $(\mathrm{OG})$}

OG content was determined by the solvent extraction method HORIBA S-316 and subsequent infrared spectrophotometric analysis using the HORIBA OCMA 350 equipment [17].

\subsubsection{Chemical Oxygen Demand (COD)}

COD was determined according to the method described by Baird et al. (2012) [17], in which the sample is digested in the presence of sulphochromic solution, silver sulphate (catalyst) and mercury sulphate (to remove chlorides). Sample digestion was performed in an ACD LABOR thermoreactor using borosilicate tubes with screw caps at $150 \pm 2^{\circ} \mathrm{C}$ for 2 hours. The determination of COD was performed by measuring the absorbance of the sample digested at wavelength of 600 $\mathrm{nm}$ in a KASUAKI spectrophotometer, model IL-226.

\subsubsection{Coagulation and Flocculation Assay}

The coagulation-flocculation tests were performed using a PoliControl jar test, model Floc Control II; aluminium sulphate was chosen as coagulating agent. The coagulation process was conducted in stages, namely: rapid mixing at $120 \mathrm{rpm}$ for 2 minutes; flocculation at $20 \mathrm{rpm}$ for 15 minutes and sedimentation for 15 minutes [15]. Each mixture resulting from the coagulationflocculation test was characterized and subsequently sent to the DAF assay. The operating $\mathrm{pH}$ range for the coagulant is 5.5 to 8 [18]. Thus, the $\mathrm{pH}$ of the effluent was adjusted to this range using a $\mathrm{HCl}$ solution $0.1 \mathrm{M}$.

\subsubsection{Experimental Design}

To evaluate the best operating conditions in the coagulation / flocculation processes, a factorial design $5^{2}$ was used, in which the concentration of the coagulating agent and the additive (clay), were the independent variables. The experimental design levels and their respective real values are shown in Table 1.

Table 1: The Experimental design proposed for the biodiesel washing treatment. Factors, encoded levels and respective real values.

\begin{tabular}{cccccc}
\hline Factor & $\mathbf{- 2}$ & $\mathbf{- 1}$ & $\mathbf{0}$ & $\mathbf{1}$ & $\mathbf{2}$ \\
\hline${\text { Concentration of } \mathrm{Al}^{3+}(\mathrm{mg} / \mathrm{L})}^{2}$ & 200 & 400 & 600 & 800 & 1000 \\
\hline Concentration of clay $(\mathrm{mg} / \mathrm{L})$ & 100 & 375 & 650 & 925 & 1200 \\
\hline
\end{tabular}

Statistica 7.0 was used for the data treatment. The process efficiencies in the removal of COD, OG and turbidity were used as response variables to obtain optimal process conditions. The results were evaluated by response surface methodology.

\subsubsection{Dissolved Air Flotation (DAF) Assay}

The experimental apparatus was composed of air compressor, saturation vessel and flotation tank (Figure 1). In this system, the water was initially saturated with air under pressure of 4 bar for 30 minutes at $25^{\circ} \mathrm{C}$ [19]. Subsequently, the saturated water was added to the effluent in the proportion of $15 \%$ by volume, causing the drag of particle aggregates to the surface. Samples from 
the clarified effluent were collected from an outlet valve located at the lower half of the treatment vessel and stored at room temperature before characterization.

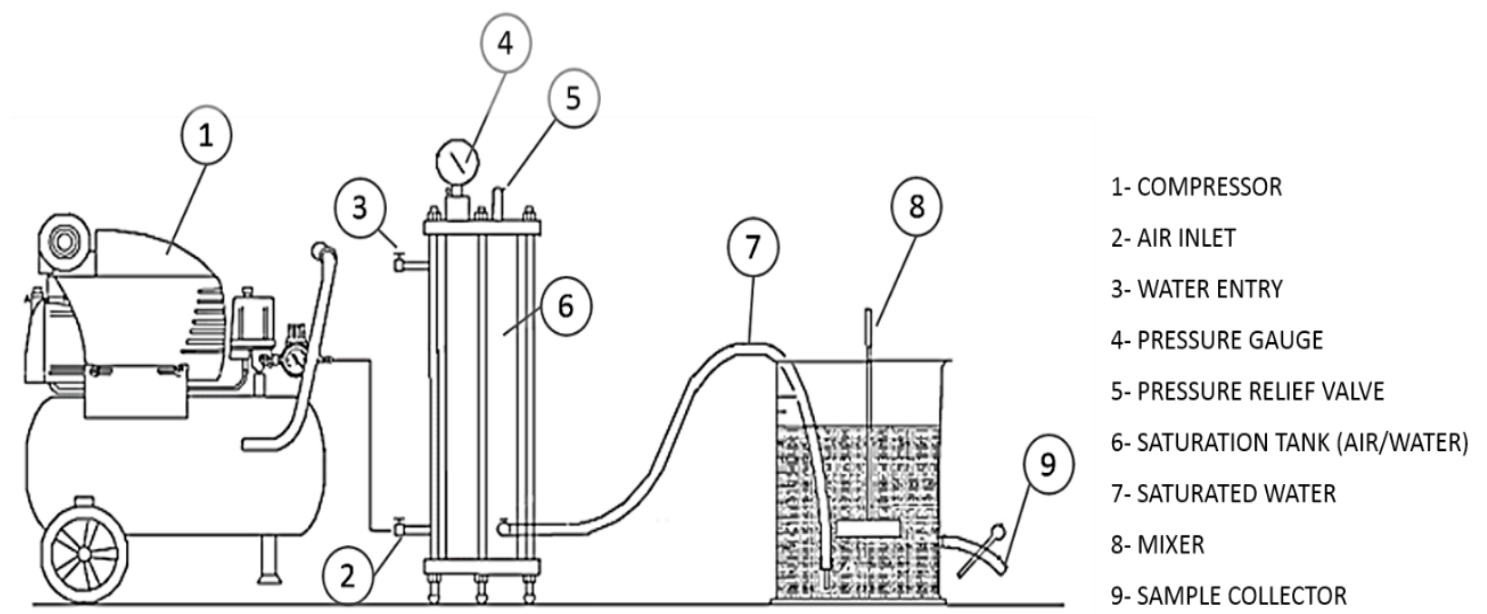

Figure 1: Graphic Representation for the Flotation System used. The system was composed of a compressor, a saturator vessel and a flotation tank.

\subsubsection{Removal Efficiency}

The results obtained in the characterization of the raw and treated effluents were used in the calculation of the efficiency of removal of the composition parameters, according to Equation 1.

$$
E_{f}^{P}=\left(1-\frac{C^{P}}{C_{0}^{P}}\right) \times 100
$$

Where $E_{f}^{P}$ is the removal efficiency (\%) for the parameter P, $C_{0}^{P}$ and $C^{P}$ are the initial and final concentrations for the parameter $\mathrm{P}$, respectively.

\section{RESULTS AND DISCUSSION}

Table 2 presents the values of the turbidity, COD and OG removal efficiencies obtained for each test shown in the factorial design. The highest turbidity removal efficiency, $92.03 \%$, was obtained when the maximum concentration of clay $\left(1200 \mathrm{mg} \cdot \mathrm{L}^{-1}\right)$ was used.

Similar behaviour was observed for the removal of OG, with maximum efficiency of $74.43 \%$, but using $200 \mathrm{mg} \cdot \mathrm{L}^{-1}$ of coagulant. For COD, the highest efficiency was $92.58 \%$, using $100 \mathrm{mg}$. $L^{-1}$ of clay and $800 \mathrm{mg} \cdot L^{-1}$ of coagulant. Figure 2 shows the response surface and respective level curves for turbidity removal.

Higher efficiencies for turbidity removal were observed in two distinct regions: (1) high clay concentrations and low concentrations of coagulant; (2) high concentrations of clay and high concentrations of coagulant. Considering economic factors, as clay is the material of lower cost, the best combination of factors corresponds to the situation (1), since it is the one that minimizes the use of the coagulating agent. On the other hand, a single optimum peak scenario was observed for OG removal, as it is shown in Figure 3 - which presents the response surface for OG removal. 
Table 2: Results for the treatment of Biodiesel Washing $(B W)$ effluent using the concentration of clay and concentration of coagulant (aluminium sulphate) as factors. The decrease in the effluent turbidity, oil and grease and chemical oxygen demand (COD) was expressed as removal efficiency and used as response variables.

\begin{tabular}{|c|c|c|c|c|c|}
\hline \multirow{2}{*}{$\#$} & \multirow{2}{*}{ Clay $(\mathrm{mg} / \mathrm{L})$} & \multirow{2}{*}{ Coagulant (mg / L) } & \multicolumn{3}{|c|}{ Removal Efficiency (\%) } \\
\hline & & & Turbidity & Oil/Grease & COD \\
\hline 1 & 925 & 600 & 86.74 & 50.34 & 36.80 \\
\hline 2 & 650 & 800 & 83.45 & 47.59 & 64.32 \\
\hline 3 & 100 & 200 & 85.18 & 53.10 & 75.32 \\
\hline 4 & 650 & 600 & 89.95 & 55.17 & 63.37 \\
\hline 5 & 1200 & 400 & 92.03 & 62.07 & 62.59 \\
\hline 6 & 650 & 1000 & 72.65 & 61.36 & 36.10 \\
\hline 7 & 1200 & 200 & 78.83 & 74.43 & 36.77 \\
\hline 8 & 100 & 600 & 67.40 & 63.64 & 28.68 \\
\hline 9 & 100 & 1000 & 68.08 & 61.93 & 23.92 \\
\hline 10 & 925 & 200 & 83.40 & 57.39 & 37.43 \\
\hline 11 & 375 & 200 & 83.91 & 73.30 & 21.49 \\
\hline 12 & 1200 & 800 & 59.82 & 46.29 & 60.91 \\
\hline 13 & 100 & 400 & 52.53 & 58.08 & 56.70 \\
\hline 14 & 375 & 600 & 55.67 & 46.72 & 61.69 \\
\hline 15 & 925 & 800 & 72.57 & 44.10 & 64.24 \\
\hline 16 & 925 & 400 & 57.59 & 54.59 & 70.33 \\
\hline 17 & 375 & 800 & 61.13 & 44.54 & 56.37 \\
\hline 18 & 925 & 1000 & 81.28 & 58.95 & 89.34 \\
\hline 19 & 100 & 800 & 77.94 & 53.71 & 92.58 \\
\hline 20 & 375 & 1000 & 80.26 & 44.98 & 70.89 \\
\hline 21 & 650 & 200 & 67.81 & 61.14 & 88.37 \\
\hline 22 & 1200 & 1000 & 91.16 & 62.76 & 64.00 \\
\hline 23 & 650 & 400 & 77.63 & 58.52 & 78.33 \\
\hline 24 & 1200 & 600 & 74.70 & 59.39 & 80.60 \\
\hline 25 & 375 & 400 & 65.59 & 68.12 & 91.61 \\
\hline
\end{tabular}

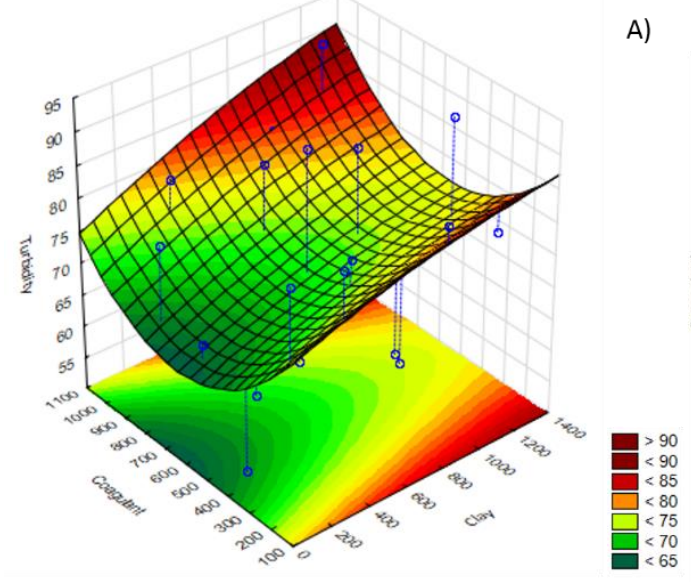

A)

B)

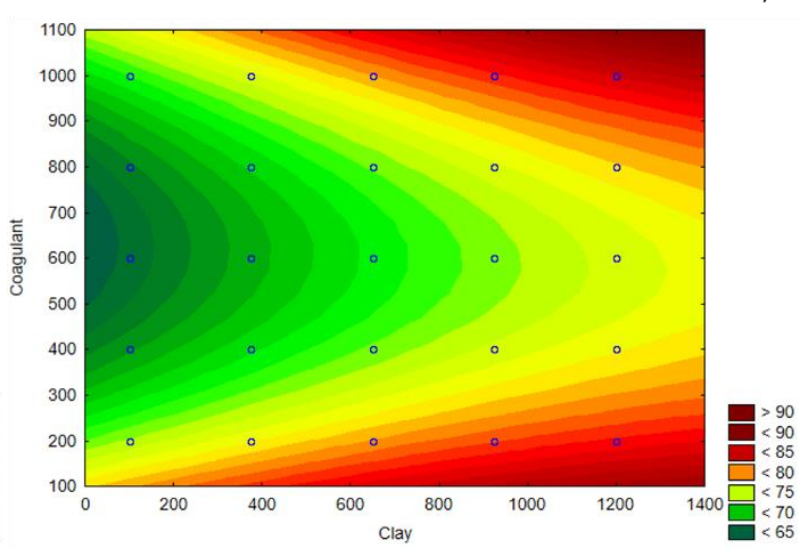

Figure 2: Response surface (A) and contour curves $(B)$ showing the effect of the coagulant and clay concentrations on the turbidity removal of the biodiesel washing effluent. 

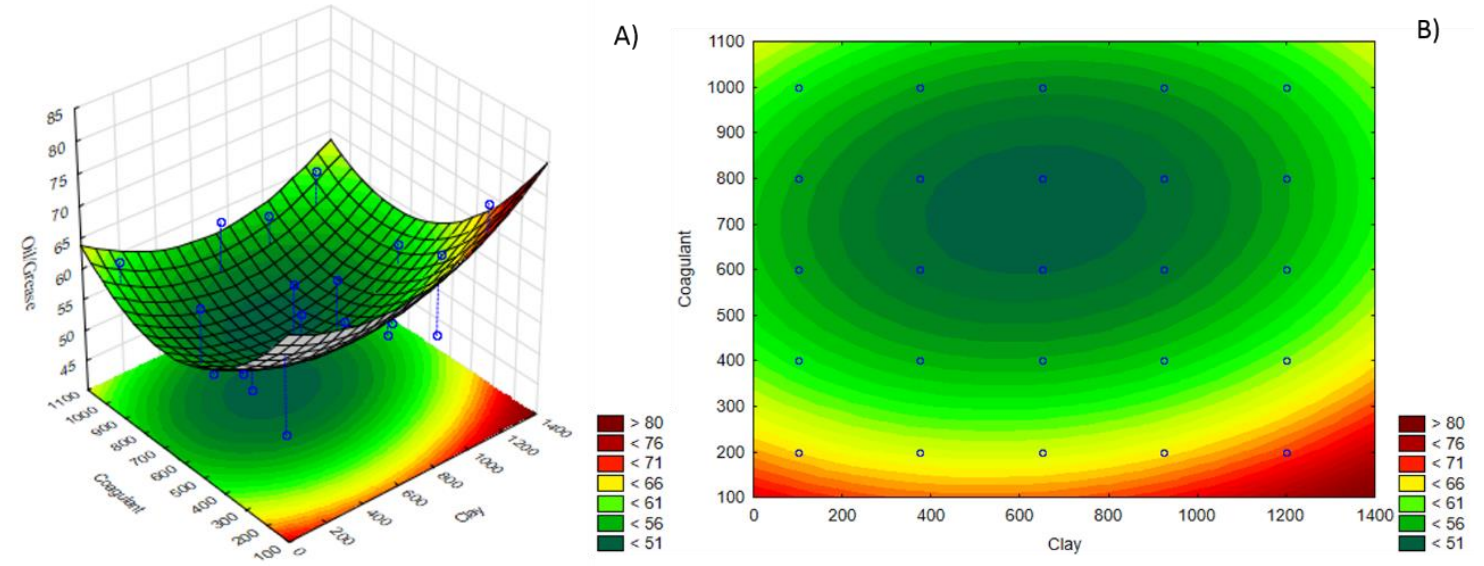

Figure 3: Effects of clay concentration and coagulant concentration on the removal of oil and grease $(O G)$ from the biodiesel washing effluent, shown as response surface (A) and level curves (B).

At such scenario, DAF treatment method is capable of decreasing both levels for turbidity and OG at favourable operational conditions - low levels of coagulant agent and high levels of clay and efficiencies comparable to more complex methods [9]. The response surface shown in Figure 4 presents COD removal efficiency as a function of the clay and coagulant concentrations.

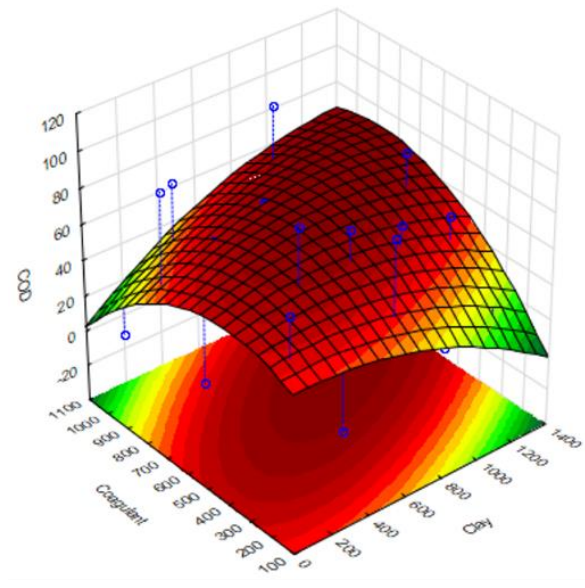

A)

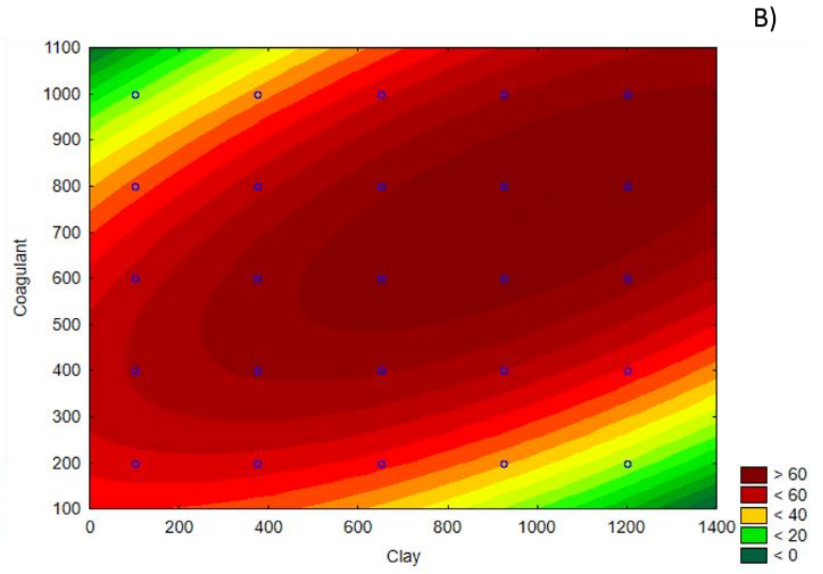

Figure 4: Response surface $(A)$ and level curves $(B)$ for the COD removal from the biodiesel production effluent as a function of the coagulant and clay concentration.

Considering the results found, it is evident that the combinations of factors that confer the highest reduction efficiencies of the three composition parameters studied (turbidity, OG and COD) were not consistent. The behaviour of the OG was not in agreement with the conclusions drawn for the COD, since the region of maximum removal of this parameter corresponds to the region of minimum removal of OG. Therefore, a test was performed without the use of clay in order to eliminate doubts as to the efficacy of this additive in the treatment process. Removal efficiencies of $24.00 \%$ for OG and $82.82 \%$ for COD were obtained. The low removal efficiency of OG in the absence of clay proves that it has a positive effect on the proposed treatment. In the experiments in which clay was used, efficiencies for the removal of OG and COD were as high as $74.43 \%$ and $92.58 \%$, respectively.

The OG contributes to the COD of the effluent, whose parameter can be subdivided into two contributions: soluble COD, related to organic compounds soluble or emulsified in aqueous medium, and insoluble COD, which is associated with the content of oils and greases or the presence of organic solids in suspension such as flocculated material. In this context, the effect of the coagulating agent is most evident in the removal of material that can be segregated in a separate 
step, such as oils and greases and the colloidal suspended solids that form flakes under certain conditions. On the other hand, soluble COD is less affected by the addition of the coagulating agent and more dependent on the presence of suspended solids with adsorption capacity to remove part of the organic molecules. From this point of view, high clay contents have greater potential to remove soluble COD by the mechanism discussed here.

\section{CONCLUSION}

The results obtained in this study show the influence of the concentration of coagulant and clay as additives for the conditioning of the effluent of biodiesel production studied in the present work in terms of the removal of turbidity, OG and COD.

According to the analysis, the best results were obtained when using $1000 \mathrm{mg} \cdot \mathrm{L}^{-1}$ of coagulant (aluminium sulphate) and $925 \mathrm{mg} \cdot L^{-1}$ of clay. This conditions yielded $81.28,58.95$ and $89.34 \%$ for turbidity, OG and COD respectively.

Thus, clay proved to be efficient as a separation additive for the removal of organic matter, mainly oils and greases, suspended solids and soluble organic matter from the biodiesel washing effluent. While those parameters are still above the limits established by the CONAMA 430 resolution, the treatment demonstrated in this manuscript successfully lowered them significatively, conditioning the effluent for the secondary - biological - treatment. In addition, the low cost attributed of using clay over traditional flocculants makes it an attractive alternative to industrial wastewater treatment processes.

\section{ACKNOWLEDGEMENTS}

Authors would like to thank FAPITEC (Fundação de Apoio à Pesquisa e Inovação Tecnológica do Estado de Sergipe), CAPES (Coordenação de Aperfeiçoamento de Pessoal de Nível Superior), and CNPq (Conselho Nacional de Desenvolvimento Científico e Tecnológico) for the financial support.

\section{REFERENCES}

1. Overland I. Future petroleum geopolitics: consequences of climate policy and unconventional oil and gas. Handbook of Clean Energy Systems. 2015:1-29, doi: 10.1002/9781118991978.hces203

2. Xu J, Li M. Innovative technological paradigm-based approach towards biofuel feedstock. Energy Convers Manage. 2017;141:48-62, doi: 10.1016/j.enconman.2016.04.075

3. García-Martínez N, Andreo-Martínez P, Quesada-Medina J, De Los Ríos AP, Chica A, Beneito-Ruiz R, et al. Optimization of non-catalytic transesterification of tobacco (Nicotiana tabacum) seed oil using supercritical methanol to biodiesel production. Energy Convers Manage. 2017;131:99-108, doi: 10.1016/j.enconman.2016.10.078

4. Lee AF, Bennett JA, Manayil JC, Wilson K. Heterogeneous catalysis for sustainable biodiesel production via esterification and transesterification. Chem Soc Rev. 2014;43(22):7887-916, doi: $10.1039 / \mathrm{C} 4 \mathrm{CS} 00189 \mathrm{C}$

5. Abdullah SHYS, Hanapi NHM, Azid A, Umar R, Juahir H, Khatoon H, et al. A review of biomass-derived heterogeneous catalyst for a sustainable biodiesel production. Renew Sust Energy Rev. 2017;70:1040-51, doi: $10.1016 /$ j.rser.2016.12.008

6. Jaruwat P, Kongjao S, Hunsom M. Management of biodiesel wastewater by the combined processes of chemical recovery and electrochemical treatment. Energy Convers Manage. 2010;51(3):531-7, doi: 10.1016/j.enconman.2009.10.018

7. Ngamlerdpokin K, Kumjadpai S, Chatanon P, Tungmanee U, Chuenchuanchom S, Jaruwat P, et al. Remediation of biodiesel wastewater by chemical-and electro-coagulation: A comparative study. J Environ Manage. 2011;92(10):2454-60, doi: 10.1016/j.jenvman.2011.05.006

8. Tanattı NP, Şengil İA, Özdemir A. Optimizing TOC and COD removal for the biodiesel wastewater by electrocoagulation. Appl Water Sci. 2018;8(2):58

9. Da Silva Brito GF, Oliveira R, Grisolia CK, Guirra LS, Weber IT, De Almeida FV. Evaluation of advanced oxidative processes in biodiesel wastewater treatment. J Photochem Photobiol A: Chem. 2019;375:8590, doi: 10.1016/j.jphotochem.2019.01.013

10. Khandegar V, Saroha AK. Electrocoagulation for the treatment of textile industry effluent-a review. $\mathrm{J}$ Environ Manage. 2013;128:949-63, doi: 10.1016/j.jenvman.2013.06.043 
11. Al-Asheh S, Aidan A. Operating conditions of coagulation-flocculation process for high turbidity ceramic wastewater. J Water Environm Nanotechnol. 2017;2(2):80-7, doi: 10.22090/JWENT.2017.02.002

12. Shankar YS, Ankur K, Bhushan P, Mohan D. Utilization of Water Treatment Plant (WTP) Sludge for Pretreatment of Dye Wastewater Using Coagulation/Flocculation. Advances in Waste Management: Springer; 2019. p. 107-21.

13. Da Silva LP, Taffarel SR, Da Silveira FR, De Sá FTC, Oliveira LFS. Treatment of effluent from rerefined lubricating oils by combined processes of coagulation, flocculation, and Fenton process. Environ Qual Manag. 2018;27(4):135-41, doi: 10.1002/tqem.21565

14. Grehs BW, Lopes AR, Moreira NF, Fernandes T, Linton MA, Silva AM, et al. Removal of microorganisms and antibiotic resistance genes from treated urban wastewater: A comparison between aluminium sulphate and tannin coagulants. Water Res. 2019;166:115056, doi: 10.1016/j.watres.2019.115056

15. Dos Santos JD, Veit MT, Juchen PT, Da Cunha Gonçalves G, Palácio SM, Fagundes-Klen M. Use of different coagulants for cassava processing wastewater treatment. J Environm Chem Eng. 2018;6(2):1821-7, doi: 10.1016/j.jece.2018.02.039

16. Silva EJ, Almeida DG, Luna JM, Rufino RD, Santos VA, Sarubbo LA. Use of bacterial biosurfactants as natural collectors in the dissolved air flotation process for the treatment of oily industrial effluent. Bioproc Biosyst Eng. 2018;41(11):1599-610, doi: 10.1007/s00449-018-1986-0

17. Baird RB, Bridgewater L, Clesceri LS, Eaton AD, Rice EW. Standard methods for the examination of water and wastewater: American Public Health Association. 22 ed. 2012.

18. Gonçalves BR, Borges Neto W, Machado AE, Trovó AG. Biodiesel wastewater treatment by coagulationflocculation: evaluation and optimization of operational parameters. J Braz Chem Soc. 2017;28(5):8007, doi: /10.21577/0103-5053.20160231

19. Etchepare R, Oliveira H, Azevedo A, Rubio J. Separation of emulsified crude oil in saline water by dissolved air flotation with micro and nanobubbles. Sep Purif Technol. 2017;186:326-32, doi: 10.1016/j.seppur.2017.06.007. 